\title{
Synthesis and characterization of $\pi$-extended porphyrins as potential precursors for the formation of columnar mesophases: Design principles for columnar mesophases need revision?
}

\author{
Beat Herzog and Reinhard Neier* \\ Department of Chemistry, University of Neuchâtel, Av. de Bellevaux 51, CH-2009 Neuchâtel, \\ Switzerland \\ E-mail: reinhard.neier@unine.ch
}

This manuscript is dedicated to Professor Heinz Heimgartner on the occasion of his $70^{\text {th }}$ birthday

\begin{abstract}
A series of meso- $\beta$ bridged extended porphyrins substituted with long aliphatic chains were synthesized and fully characterized. Two different synthetic strategies were tested to obtain the target structures. The synthetic steps were optimized in order to obtain scalable routes for the production of sufficient quantities of $\pi$-extended porphyrins for material science studies. The porphyrins were obtained either as free bases or complexed with $\mathrm{Ni}^{\mathrm{II}}$ or $\mathrm{Cu}^{\mathrm{II}}$. UV-Vis spectroscopy and polarized light microscopy was used for the analysis of the material properties of the $\pi$-extended porphyrins. The results obtained with our compounds are not compatible with the results reported in the literature.
\end{abstract}

Keywords: Extended porphyrins, materials science, liquid crystals, polarized light microscopy

\section{Introduction}

Improving the conductivity of materials forming discotic, columnar mesophases is a desirable goal in materials science. Enhanced electronic properties, especially higher conductivity of the organized, organic materials should allow the fabrication of flexible, organic electronic devices. The empirical correlation of the structures used with the observed properties is the methodology applied successfully in this field. We report on our research program aiming at the synthesis of raffled porphyrins as new building blocks for the formation of discotic, columnar mesophases.

In discotic, columnar mesophases the disorder of the packing is an important factor which reduces the conductivity of the material. Avoiding the slipping of the disks and thereby enhancing the order and the density of the packing should strengthen the $\pi-\pi$ interactions 
between the aromatic rings forming the disks. The higher order and the better packing should boost the conductivity in the directions of the columns. Distorting the planar structure of the $\pi$ system so as to obtain a raffled surface will change the electronic properties. Changing from a flat to a raffled, more "rough" surface will simultaneously modify the geometric properties of the compounds and thereby influence the packing of the discotic, columnar mesophases. The overall goal of our research project is the synthesis of raffled porphyrins capable to form discotic, columnar mesophases with improved electronic properties of the material.

Synthetic porphyrins and chlorins have been intensively studied. The vital functions of the natural tetrapyrrolic cofactors have been the major motivation for many of these research projects. Characteristic goals of these studies were: mimicking photosynthesis, ${ }^{1}$ imitating cytochrome $\mathrm{P} 450$ catalyzed oxidations ${ }^{2}$ and transporting oxygen. ${ }^{3}$ In a complementary approach chemists tried to exploit the photopysical and photochemical properties of porphyrins in photodynamic therapy ${ }^{4}$ and in materials science. ${ }^{5}$

Several design strategies have been successfully applied modifying porphyrins so as to obtain discotic mesophases. ${ }^{5-7}$ Due to the ease and efficiency of their synthesis mesotetraphenylporphyrins have been widely used as model compounds and as porphyrin building blocks to create novel structures with interesting chemical, biological, medicinal and material science properties. Meso-tetraphenylporphyrins substituted in the para position with four long aliphatic chains have been reported to form discotic liquid crystalline mesophases. ${ }^{7}$ This design principle reported in the literature was used as starting point for our studies. Relying on this literature report we hoped that meso-tetraphenylporphyrins or derivatives obtained from these tetraphenylporphyrins would already exhibit liquid crystalline behavior if substituted in their para positions by four aliphatic chains of the length $\mathrm{C}_{8}, \mathrm{C}_{10}$ or $\mathrm{C}_{12}$.

In meso-tetraphenylporphyrins the four phenyl groups are in a conformation, which is nearly orthogonal to the planar disk of the porphyrin $\pi$-system. The phenyl rings extend farther in the direction orthogonal to the porphyrin-disk than the $\pi$-system. The presence of the phenyl rings should therefore be the factor limiting the density of the packing of the disks in the stacks forming the discotic mesophase. Introducing bridges linking the phenyl group to one of the neighboring $\beta$-positions of a pyrrole ring forces the phenyl ring into a conformation, which is nearly aligned with the porphyrin plane. ${ }^{8}$ Constructing discotic columnar mesophases from meso-bridged porphyrins has the potential to create useful elements for directed, one dimensional electron transfer processes.

Typical metal free meso-tetraphenylporphyrins (TPP's) have an absorption maximum at 650 nm. ${ }^{9}$ Expanded $\pi$-systems, the so called $\pi$-extended porphyrins, show a bathochromic shift in their absorption spectrum. Attaching suitable substituents on the $\beta$ - or on the meso-position of the porphyrin expands the conjugation of the original porphyrin chromophore. ${ }^{10,11}$ Porphyrin derivatives, where a carbonyl group forms a bridge between a $\beta$-pyrrole position and an $o$ position of a neighbouring meso-phenyl group, have been reported. ${ }^{12,13}$ This novel chromophore was characterized by a strong batochromic shift of the Soret band from $420 \mathrm{~nm}$ to $470 \mathrm{~nm}$. Callot 
and co-workers developed a powerful Friedel-Crafts methodology for the synthesis of mono- and dicarbonyl bridged extended porphyrins. ${ }^{14,15}$

In this work we report two synthetic sequences adapted for the construction of bridged, $\pi$ extended porphyrins substituted with long alkyl or alkanoyloxy chains. We needed reliable and scalable synthetic procedures for these precursors in order to obtain sufficient quantities of our target molecules. Introducing different long chains into our precursors had to be facile, so that the material properties of the final porphyrin products can be fine-tuned. We tested the FriedelCrafts acylation methodology for the synthesis of mono-bridged target molecules first. This process delivers well defined products of the final cyclisation reaction. The alternative sequence $\beta$-formylation-cyclisation is a convenient alternative for the introduction of one fused bridge. This approach allows obtaining only mono-bridged extended porphyrins. ${ }^{16}$

The compounds we obtained were fully characterized and purified. In contrast to the results reported in the literature our compounds did not show any liquid crystalline behavior. For comparison reasons we synthesized also the compounds $\mathbf{1 3 a}$ and $\mathbf{1 3 b}$, which have been reported to show liquid crystalline phases. In contrast to the literature reports compounds 13a and 13b did not show any liquid crystalline phase in our hands. We have not been able to elucidate the reasons for this difference. As our design has been based on the properties reported in the literature, we will have to modify the design of our $\pi$-extended porphyrins in order to obtain liquid crystalline phases. To establish a structure property relationship we need to have access to the substituted tetraphenylporphyrins and the substituted $\pi$-extended porphyrins to be able to compare the material properties of both classes of compounds with each other.

\section{Results and Discussion}

Two retrosynthetic strategies have been reported to obtain meso- $\beta$ bridged $\pi$-extended porphyrins. Adapting these strategies to the synthesis of our target molecules leads to the two synthetic approaches presented in Schemes 2 and 3. In one approach (Scheme 2) the long chains are introduced before the macrocyclization leading to the porphyrins $9 \mathbf{a}, 9 \mathbf{b}, \mathbf{1 0 a}$ and $\mathbf{1 0 b}$. In this approach the carbonyl bridge is introduced in the last step of the synthesis. Metal complexes are used to protect the porphyrin system against the harsh condition needed for the Friedel-Craft acylation or alternatively the Vilsmeier-Haack formylation, the final steps in this sequence. In the second approach the tetrakis- $p$-methoxy-tetraphenylporphyrin is transformed into the nickel complex and then treated under Vilsmeier-Haack condition to introduce the carbonyl bridge. The nickel and the four methyl groups are then removed sequentially and the different acid chlorides containing long aliphatic chains are introduced to give the compounds 12a to 12c. In this short sequence the aliphatic chains are introduced last and the metal-free porphyrin is obtained.

The adequate precursors $\mathbf{1}$ and $\mathbf{2}$ have to be synthesized for the approach based on the FriedelCraft acylation reaction to establish the meso-bridge. The bromo or methoxy substituent in the 
meta position to the ester has been chosen so as to allow the introduction of long chains in order to obtain the material properties needed for the formation of liquid crystalline phases.

\section{Synthesis of the building blocks}

In order to obtain adequate precursors $9 \mathbf{a}$ and $9 \mathbf{b}$ for the Friedel-Crafts cyclisation we focused on the synthesis of the two molecules 1 and 2 first. Both molecules can be obtained starting from $o$ toluic acid 3 in a view straightforward synthetic steps (see Scheme 1). ${ }^{17,18}$ Bromination of $o$ toluic acid was performed in a heterogenic medium, catalyzed by $\mathrm{Fe}$, giving a mixture of mainly 4a, some starting material $\mathbf{3}$ and the 3-bromo isomer. The corresponding methyl ester, obtained after Fischer esterification could be separated by distillation followed by fractionated crystallization. The methyl-5-bromobenzoate 5a could be obtained in high purity and in a sequence avoiding any chromatographic separation. ${ }^{19,20}$

The synthesis of 5-hydroxy-o-toluic acid $\mathbf{4 b}$ follows the described procedure ${ }^{18}$. Methylation with dimethylsulfate yielded 5-methoxy-o-toluic acid $4 \mathbf{c}$ in almost $60 \%$ yield. Fischer esterfication gave the methyl-5-methoxy-o-toluate $\mathbf{5 b}$ in over $90 \%$ yield. The benzylic dibromination of $\mathbf{5 a}$ and $\mathbf{5 b}$ gave quantitatively the benzalbromides $\mathbf{6 a}$ and $\mathbf{6 b}$. These benzalbromides were hydrolyzed in good yields in the presence of $\mathrm{AgNO}_{3}$ to the building blocks $\mathbf{1}$ and 2. $^{21,22}$

In our hands the method developed for the synthesis of $\mathbf{1}$ was more convenient than the synthesis of 2 described earlier in the literature. ${ }^{23}$

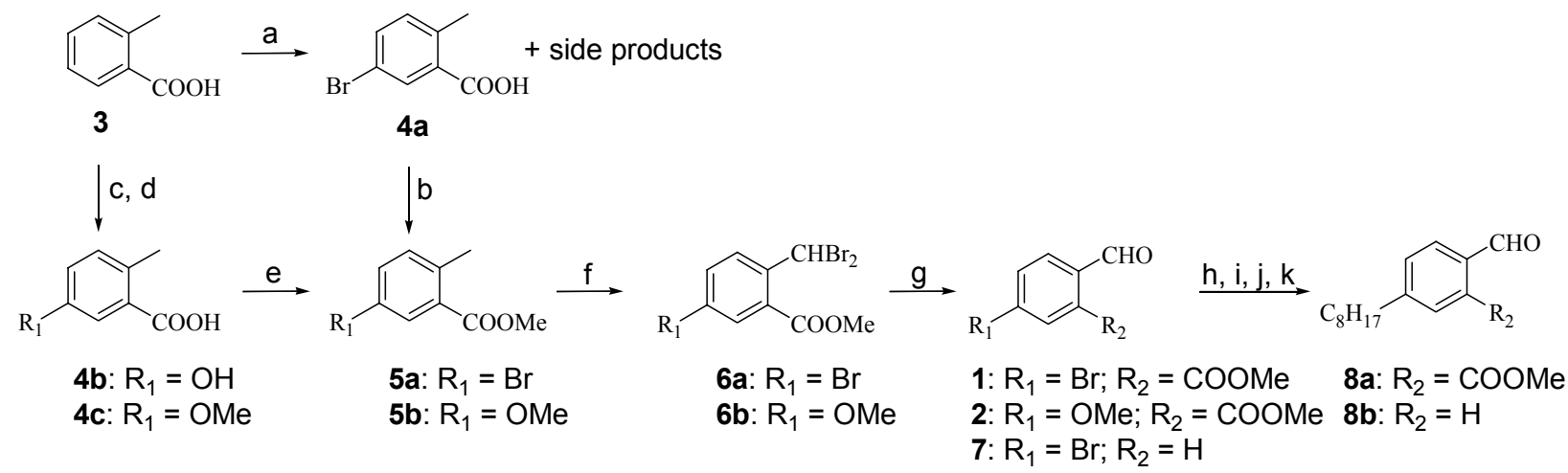

Scheme 1. Synthesis of building blocks 2, 8a and 8b. Reagents and conditions: a: $\mathrm{Br}_{2}, \mathrm{Fe}$ (cat.), $0{ }^{\circ} \mathrm{C} \rightarrow \mathrm{RT}, 16$ h, 99\%; b: $\mathrm{MeOH}, \mathrm{H}_{2} \mathrm{SO}_{4}$ (cat.), RF, 15 h, 21.6\%; c: $\mathrm{H}_{2} \mathrm{SO}_{4}, 160{ }^{\circ} \mathrm{C}, 2.5$ h, $\mathrm{KOH}$, $190{ }^{\circ} \mathrm{C}, 2.5 \mathrm{~h}, \mathrm{HCl}$ (concentrated), 37.4\%; d: $\left(\mathrm{CH}_{3}\right)_{2} \mathrm{SO}_{4}, \mathrm{KOH}$ (aq.), RF 16 h, 56.8\%; e: $\mathrm{MeOH}$, $\mathrm{H}_{2} \mathrm{SO}_{4}$ (cat.), RF, 16 h, 93.6\%; f: NBS, $\left(\mathrm{PhCO}_{2}\right)_{2}$ (cat.), $\mathrm{CCl}_{4}, \mathrm{RF}, 14-15$ h, 100\%; g: $\mathrm{AgNO}_{3}$, $\mathrm{H}_{2} \mathrm{O} / i$-PrOH (1:10), RT, dark, 3 - 4 h, 1: 94\%, 2: 82\%; h: 1-octene, $\mathrm{Pd}(\mathrm{OAc})_{2}$ (cat.), $\mathrm{P}(o-\mathrm{Tol})_{3}$ (cat.), DMF, $\mathrm{NEt}_{3}$, RF, 1.5 h - 16 h; i: $\mathrm{CH}(\mathrm{OMe})_{3}, \mathrm{MeOH}, \mathrm{NH}_{4} \mathrm{Cl}$ (cat.), RF, 16 h - 48 h; j: $\mathrm{Pd} / \mathrm{C}$ (cat.), $\mathrm{H}_{2}$, EtOH, RT, 3 - 4.5 h; k: $\mathrm{CH}_{2} \mathrm{Cl}_{2}$ or THF, $2 \mathrm{~N} \mathrm{H}_{2} \mathrm{SO}_{4}$, RT, 15 h; yields h - k: 8a: 47\%, 8b: $81 \%$; 
Having sufficient quantities of compounds $\mathbf{1}$ and $\mathbf{2}$ in our hands we were able to test these molecules as potential precursors for our extended porphyrins: the methyl ester would be needed for the Friedel-Crafts cyclisation reaction. The bromo and methoxy substituent on the aromatic ring were intended to allow the introduction of long chains via $\mathrm{C}$-C-bond formation reactions like Heck and Suzuki coupling or simple esterification or etherification methods after deprotection of the methoxy group.

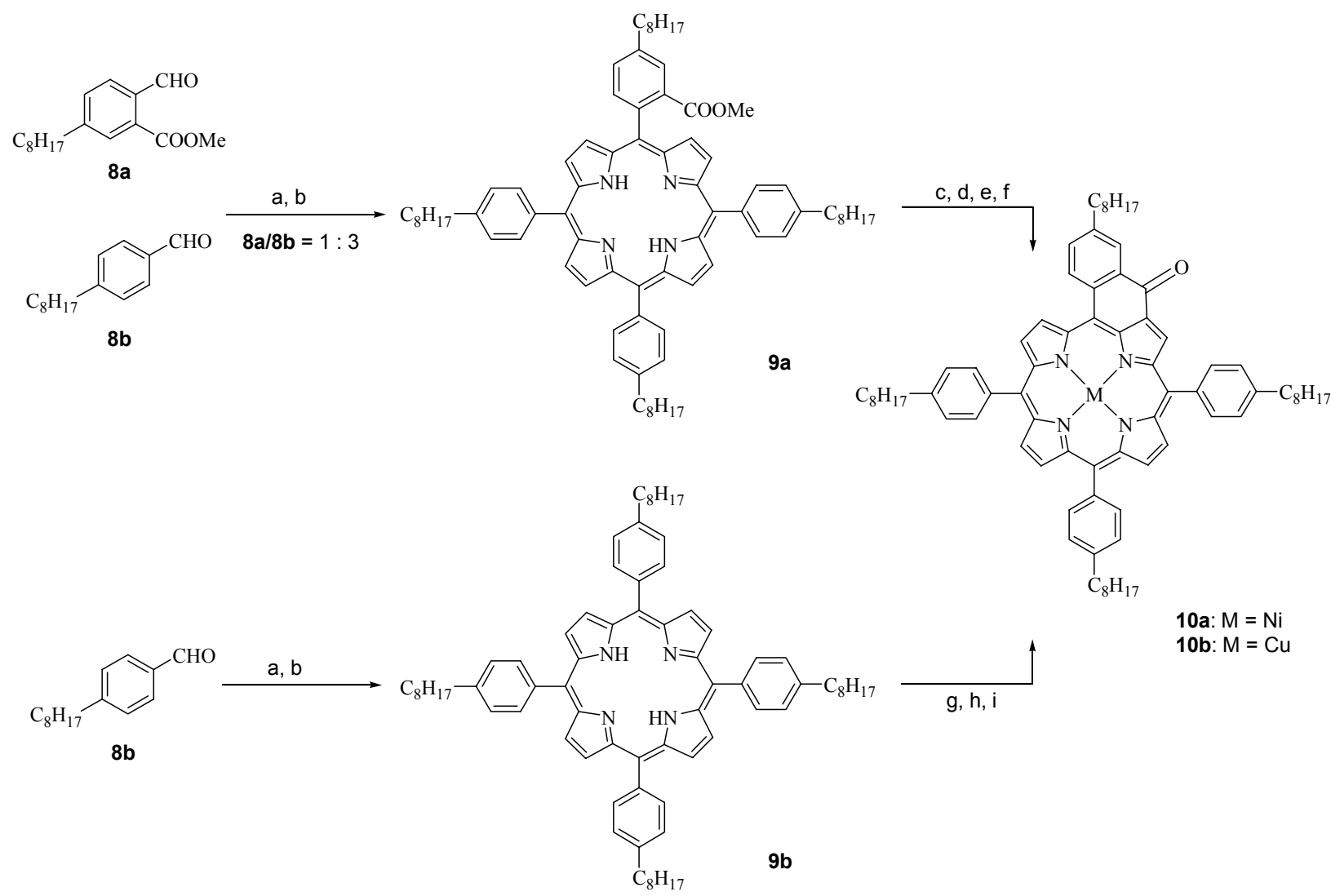

Scheme 2. Synthesis of alkyloxonaphtoporphyrins 10a and 10b. Reagents and conditions: a: Pyrrole, $\mathrm{Bu}_{3} \mathrm{BnNCl}$ (cat.), $\mathrm{BF}_{3} \cdot \mathrm{Et}_{2} \mathrm{O}$ (cat.), RT, 10 min.; b: DDQ, RT, 2 h, $\mathrm{NEt}_{3}$; yields a - b: 9a: 12\%, 9b: 45\%; c: Ni(acac) $)_{2}$, toluene, RF, 16 h; d: KOH, $\mathrm{H}_{2} \mathrm{O} /$ dioxane (2:1), RF, 20 h; e: $(\mathrm{COCl})_{2}, \mathrm{C}_{6} \mathrm{H}_{6}, \mathrm{RF}, 18 \mathrm{~h}$; f: $\mathrm{SnCl}_{4}, \mathrm{C}_{6} \mathrm{H}_{6}, \mathrm{RT}, 1 \mathrm{~h}$; yield c - f: $92 \%$; $: \mathrm{Cu}(\mathrm{OAc})_{2}, \mathrm{MeOH} / \mathrm{CH}_{2} \mathrm{Cl}_{2}$ (2:1), RF, 16 h; h: DMF, $\mathrm{POCl}_{3}$, 1,2-dichloroethane, RF, 18 h; i: TsOH $\cdot \mathrm{H}_{2} \mathrm{O}$ (cat.), chloranil, 1,2dichloroethane, RF, 16 h; yield g - i: 10a: 33\%.

\section{Synthesis of alkyl substituted oxonaphthoporphyrins (10a, 10b)}

Our initial efforts concentrated on the modification of compound 1. We wanted to apply the following strategy: 1) Introduction of the long chain via C-C-bond formation using the Heck coupling 2) Synthesis of TPP 3) Friedel-Crafts cyclisation to the oxonaphthoporphyrin. Two substrates are known to react with high regioselectivity in the Heck reaction: acrylates and $p$ - 
alkoxystyrenes. $^{24}$ Other alkenes often give complex mixtures of isomers. ${ }^{25}$ The reaction conditions could be successfully tested with acrylates (results not reported). They are however not resistant enough against the strong basic reaction conditions needed in later steps of the synthetic sequence. The $p$-alkoxystyrenes are easily prepared starting from $p$ hydroxybenzaldehyde via etherification and a subsequent Wittig reaction. Unfortunately they seem not to be suitable for the formation of mesophases. ${ }^{20}$ Synthesizing styrenes containing two or three long aliphatic chains multistep sequences have to be applied, which seemed to be too cumbersome at this stage. ${ }^{19}$ Using $1-n$-alkenes as vinylating agents is easy to perform and the selectivity problem is partially solved. Reduction of the product of the Heck reaction should mainly give the 1-isomer with minor amounts of the 2-isomer. Substituted porphyrins containing $n$-alkyl chains have been described to form discotic mesophases. ${ }^{6}$ Based on this literature precedent we were confident, that we should observe liquid crystalline behaviour with our target molecules.

We cyclised our precursors $9 \mathbf{a}$ and $9 \mathbf{b}$ to the $p$-alkyl substituted oxonaphthoporphyrins via two different methods (see Scheme 2). The procedure cyclising the porphyrin in a Friedel-Crafts type acylation was successfully tested with compound 9a. The molecule 9a had been obtained from 1 by Heck vinylation using 1-octene followed by a reduction of the double bond. ${ }^{26}$ The porphyrin synthesis was made under modified Lindsey conditions. ${ }^{27,28}$ The porphyrin 9a was then converted into the oxonaphthoporphyrin 10a via the Friedel-Crafts reaction sequence described by Callot. ${ }^{15}$

For the second route a Vilsmeier-Haack formylation was used to introduce the additional carbon atom. The starting material of this sequence was $p$-bromobenzaldehyde. The same synthetic steps were used as for the first route until the porphyrin forming step. The porphyrin $9 \mathbf{b}$ was complexed with a $\mathrm{Cu}^{\mathrm{II}}$-acetate. One of the pyrrolic $\beta$-positions was formylated under Vilsmeier-Haack conditions. Without isolation the intermediate was cyclised in the presence of $p$ - $\mathrm{TsOH} \cdot \mathrm{H}_{2} \mathrm{O}$ and chloranil was used as oxidant to obtain $\mathbf{1 0 b} .^{14}$ The overall yield of this sequence is $33 \%$ compared to the overall yield of $92 \%$ obtained via the Friedel-Crafts strategy.

\section{Synthesis alkanoyloxy substituted oxonaphthoporphyrins (12a-12c)}

The synthesis of oxonaphthoporphyrin $\mathbf{1 1}$ has been reported in the literature. ${ }^{29}$ Compound $\mathbf{1 1}$ is a suitable starting material to obtain extended porphyrins carrying long chains when esterified with the adequate acids. The synthetic sequence starting from readily available $\mathbf{1 1}$ is short and convenient (see Scheme 3). Compound 11 was de-metallated in $\mathrm{TFA} / \mathrm{H}_{2} \mathrm{SO}_{4}$ followed by a classical de-methylation with $\mathrm{BBr}_{3}$ in $\mathrm{CH}_{2} \mathrm{Cl}_{2}$. The obtained tetrahydroxyoxonaphthoporphyrin was then reacted with different acyl chlorides to obtain the products $12 \mathbf{a}-\mathbf{1 2 c}$ in moderate yields.

The alternative Friedel-Crafts route for the synthesis of $\mathbf{1 1}$ starting from $\mathbf{2}$ could not be applied. Separating the different porphyrin esters obtained proved to be difficult. The product was partially destroyed during the harsh conditions needed for the cyclisation forming the 
additional ring of the $\pi$-extended porphyrin. Using this alternative approach the extended porphyrins could not be obtained in pure form.

The advantage of the approach using compound $\mathbf{1 1}$ as starting material is clearly that the chains needed for creating liquid crystalline properties are introduced late in the sequence. The most delicate experimental point in this sequence is the incomplete esterification. The separation of the partially esterified products from the fully esterified products 12a - 12c by different chromatographic methods is tedious and not very efficient.

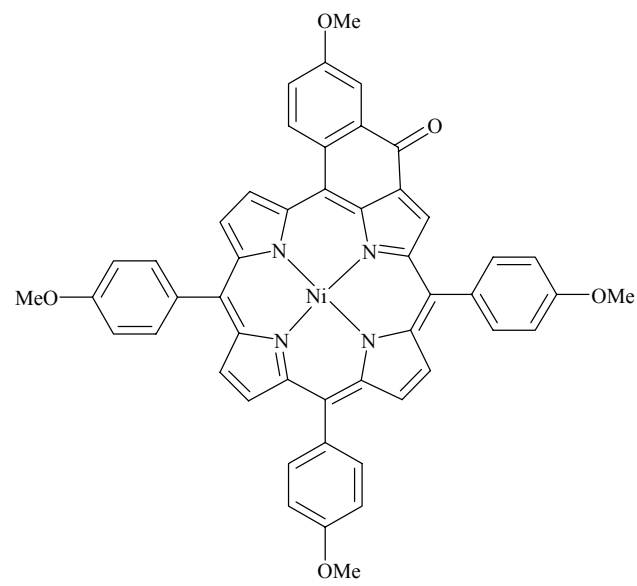

11

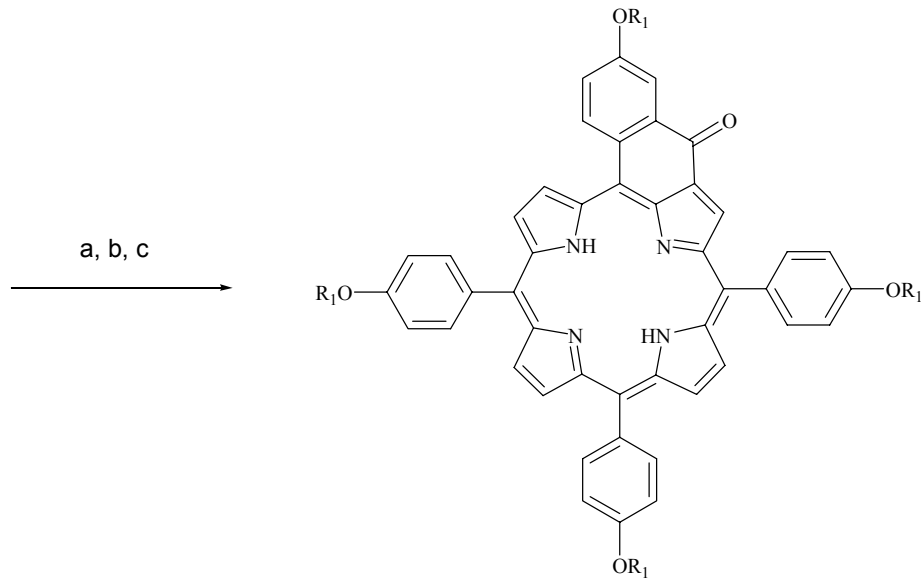

12a: $\mathrm{R}_{1}=\mathrm{CO}\left(\mathrm{CH}_{2}\right)_{8} \mathrm{CH}_{3}$ 12b: $\mathrm{R}_{1}=\mathrm{CO}\left(\mathrm{CH}_{2}\right)_{10} \mathrm{CH}_{3}$ 12c: $\mathrm{R}_{1}=\mathrm{CO}\left(3,5-\right.$ di-OC $_{12} \mathrm{H}_{25}$-phenyl)

Scheme 3. Synthesis of oxonaphthoporphyrins 12a - 12c. Reagents and conditions: a: TFA $/ \mathrm{H}_{2} \mathrm{SO}_{4}$ (5:1), RT, 30 min., 65\%; b: $\mathrm{BBr}_{3}, \mathrm{CH}_{2} \mathrm{Cl}_{2}$, RT, 20 h, 79\%; c: $\mathrm{R}_{1} \mathrm{COCl}$, Toluol/DMF/NEt 3 , RF, 16 - 20 h, 12a: 46\%, 12b: 46\%, 12c: $27 \%$.

The choice for introducing C10- and C12-alkanoyloxy chains was based on a literature report describing tetraphenylporphyrins modified with $\mathrm{C} 10$ - and $\mathrm{C} 12$-alkanoyloxy chains are forming hexagonal columnar mesophases. ${ }^{7}$

We resynthesized the two tetraphenylporphyrins 13a and 13b (Figure 1) as reference substances for the comparison of their mesomorphic behaviour with the behaviour of our oxonaphthoporphyrins $12 \mathbf{a}$ and $\mathbf{1 2 b}$. 


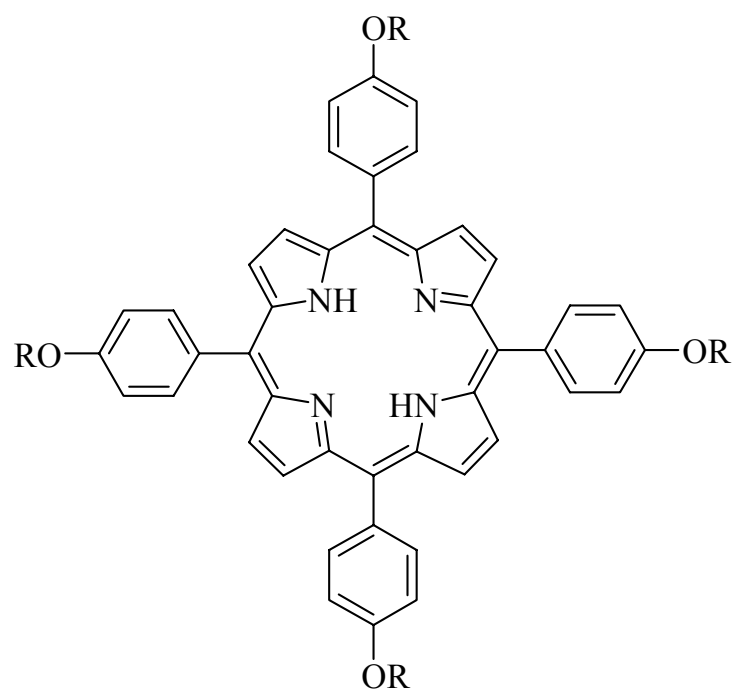

13a: $\mathrm{R}=\mathrm{CO}\left(\mathrm{CH}_{2}\right)_{8} \mathrm{CH}_{3}$

13b: $\mathrm{R}=\mathrm{CO}\left(\mathrm{CH}_{2}\right)_{10} \mathrm{CH}_{3}$

Figure 1. The two mesophase forming tetraphenylporphyrins 13a and 13b described in the literature. $^{7}$

\section{Measurements with polarized light microscopy}

All the new oxonaphthoporphyrins were carefully tested with polarized light microscopy to determine their mesomorphic properties. No liquid crystalline behavior could be observed. The compound 12b showed no clear phase transition. As described by Shimizu our reference substance 9a showed mesomorphic properties. ${ }^{6}$ The isotropisation temperature for 9a was lower than in the literature. The lowering of the isotropisation temperature can be attributed to the presence of small amounts of branched chains in our samples. For the tetraphenylporphyrins 13a and 13b mesomorphism has been described in the literature. ${ }^{7}$ We have not been able to reproduce these observations, even when the compounds were carefully purified by HPLC.

Table 1. Transition temperatures measured under polarized light microscope

\begin{tabular}{ccccccccc}
\hline & $\mathbf{9 a}$ & $\mathbf{1 0 a}$ & $\mathbf{1 0 b}$ & $\mathbf{1 2 a}$ & $\mathbf{1 2 b}$ & $\mathbf{1 2 c}$ & $\mathbf{1 3 a}$ & $\mathbf{1 3 b}$ \\
\hline $\mathrm{T}_{\text {trans }}\left({ }^{\circ} \mathrm{C}\right)$ & & & 150 & 65 & n.d. & 60 & 165 & 151 \\
transition & & $\mathrm{I}$ & $\mathrm{I}$ & $\mathrm{I}$ & $\mathrm{I}$ & $\mathrm{I}$ & $\mathrm{I}$ & $\mathrm{I}$ \\
$\mathrm{LC}$ & yes & no & no & no & no & no & no & no \\
\hline
\end{tabular}




\section{Conclusions}

We report the scalable synthesis of two appropriate precursor building blocks $\mathbf{1}$ and $\mathbf{2}$ for the synthesis of functionalised oxonaphthoporphyrins. The vinylation of $\mathbf{1}$ under Heck conditions followed by porphyrin formation and cyclisation lead to oxonaphthoporphyrin 10a. The copper complex 10b was obtained by the $\beta$-formylation-cyclisation route. Using the building block 2 in this sequence lead to problems during the Friedel-Crafts cyclisation step. A direct and efficient synthesis of oxonaphthoporphyrins 12a to 12c with peripheral ester functionalities using the oxonaphthoporphyrin 11 was developed. Analysing the mesomorphic properties of the new oxonaphthoporphyrin 10a, 10b and 12a to 12b with polarized light microscopy indicated no liquid crystalline properties for any of the novel compounds reported in this publication. The two molecules 13a and 13b reported in the literature and resynthesized by us, did not show any mesomorphic behavior either. ${ }^{7}$ We purified these compounds extensively and characterized them completely, so to be sure that we had the correct molecules in our hand. Despite this effort no liquid crystalline behavior could be observed.

\section{Experimental Section}

General. Chemicals were obtained from Fluka and Aldrich. Dried solvents were purchased from commercial sources and stored over molecular sieves. All the reaction solvents are puriss. quality. Solvents for extraction and chromatography were technical quality. They were distilled over an appropriate drying agent before use. Column chromatography was carried out on silica gel 60 from Fluka ( $\mathrm{SiO} 2,230$ - 400 mesh, particle size $0.050-0.150, \mathrm{pH}=7.0+/-0.5$ ). Analytical thin-layer chromatography was performed on Merck silica or aluminium oxide basic gel plates with QF-254 indicator. Visualization was accomplished with UV light and/or potassium permanganate. ${ }^{1} \mathrm{H} N M R$ and ${ }^{13} \mathrm{C}$ NMR spectra were recorded on a Bruker Avance-400 spectrometer $\left(400 \mathrm{MHz},{ }^{1} \mathrm{H} ; 100 \mathrm{MHz},{ }^{13} \mathrm{C}\right)$ at $298 \mathrm{~K}$. Spectra are referenced to the residual solvent peak. ${ }^{30}$ Chemical shifts are reported in ppm $(\delta)$; multiplicities are indicated by s (singlet), $\mathrm{d}$ (doublet), $\mathrm{t}$ (triplet, q (quartet), $\mathrm{m}$ (multiplet) and br (broad). Coupling constants, $J$, are reported in Hertz. Mass spectra were measured on a Thermo Finnigan LCQ mass spectrometer. HR-MS spectra were obtained on a Bruker BioAPEX II daltonics mass spectrometer. Data are reported in the form of $\mathrm{m} / \mathrm{z}$ (intensity relative to base peak $=100$ ). Ionization methods for the mass spectra are indicated in the experimental part. Infrared spectra (IR) were recorded on a Perkin Elmer Spectrum One FT-IR spectrophotometer in $\mathrm{NaCl}$ cells (film) or as $\mathrm{KBr}$ plate. Peaks are reported in $\mathrm{cm}^{-1}$ with indicated relative intensities: s (strong, 67-100\%); $\mathrm{m}$ (medium, 34 66\%), w (weak, 0-33\%). UV-vis spectra were measured on a HP 8452 diode array spectrophotometer using quartz cuvettes $(1.00 \mathrm{~cm})$. The wavelength of the absorption maxima (1) is indicated in $\mathrm{nm}$ (intensity relative to the strongest maxima $=100$ ). 
5-Bromo-o-toluic acid (4a). Bromine $(22.5 \mathrm{~mL}, 440 \mathrm{mmol})$ was added to a slurry of $o$-toluic acid (50g, $367 \mathrm{mmol}$,) and iron powder $(1.1 \mathrm{~g}, 19.7 \mathrm{mmol})$ over a period of $15 \mathrm{~min}$. at $0^{\circ} \mathrm{C}$. The mixture was stored overnight at RT and then flushed with $\mathrm{N}_{2}$. The solid cake was taken up in AcOEt and this solution washed with a saturated $\mathrm{Na}_{2} \mathrm{~S}_{2} \mathrm{O}_{3}$ and $\mathrm{H}_{2} \mathrm{O}$. The organic layer was dried $\left(\mathrm{MgSO}_{4}\right)$ and the solvent evaporated. After drying a white solid $(78.4 \mathrm{~g}, 99 \%)$ was obtained as a mixture consisting mainly of $\mathbf{4 a}(58.4 \%)$, 3-bromo-o-toluic acid (25.7\%) and starting material (15.8\%) as indicated by the ${ }^{1} \mathrm{H}$ NMR spectrum. ${ }^{1} \mathrm{H} \mathrm{NMR}\left(400 \mathrm{MHz}, \mathrm{CDCl}_{3}\right): \delta=8.10(\mathrm{~d}, J=2.3$ $\mathrm{Hz}, 1 \mathrm{H}), 7.48$ (dd, $J=8.2 \mathrm{~Hz}, 2.3 \mathrm{~Hz}, 1 \mathrm{H}), 7.10$ (d, $J=8.2 \mathrm{~Hz}, 1 \mathrm{H}), 2.55$ (s, $3 \mathrm{H}) \mathrm{ppm}$.

Methyl-5-bromo-o-toluate (5a). The raw material obtained above containing 4a (75.0 g, 349 mmol) was dissolved in a solution of $\mathrm{MeOH}(400 \mathrm{~mL})$ and $\mathrm{H}_{2} \mathrm{SO}_{4}(5.0 \mathrm{~mL}, 88.5 \mathrm{mmol})$. The solution was heated to reflux for $15 \mathrm{~h}$. After removing the $\mathrm{MeOH}$ under reduced pressure, the residue was dissolved in AcOEt $(350 \mathrm{~mL})$ and washed with $\mathrm{H}_{2} \mathrm{O}(20 \mathrm{~mL})$. The aqueous layer was extracted with AcOEt $(100 \mathrm{~mL})$. The combined organic extracts were washed with saturated $\mathrm{NaHCO}_{3}(3 \times 50 \mathrm{~mL})$ and $\mathrm{H}_{2} \mathrm{O}(2 \times 50 \mathrm{~mL})$ and dried $\left(\mathrm{MgSO}_{4}\right)$. Removal of the solvent in a rotary evaporator afforded a yellowish, transparent liquid $(77.9 \mathrm{~g})$ which was distilled under vacuum to obtain a mixture consisting mainly of 5a and its 3-bromo isomer. This raw product was put in a refrigerator (at $6{ }^{\circ} \mathrm{C}$ ). The crystallized solid was filtered off and dried by sucking air through the filter cake for $3 \mathrm{~h}$. This procedure was repeated several times with the mother liquors. Combining the resulting solids 5a was obtained in high purity as a white solid (17.3 g, $22 \%) . \mathrm{R}_{\mathrm{f}}$ (Hexane/AcOEt 4:1): 0.65. mp: $52{ }^{\circ} \mathrm{C} .{ }^{1} \mathrm{H} \mathrm{NMR}\left(400 \mathrm{MHz}, \mathrm{CDCl}_{3}, 300 \mathrm{~K}\right): \delta=8.03$ $(\mathrm{d}, J=2.1 \mathrm{~Hz}, 1 \mathrm{H}), 7.49(\mathrm{dd}, J=8.0 \mathrm{~Hz}, 2.1 \mathrm{~Hz}, 1 \mathrm{H}), 7.11(\mathrm{~d}, J=8.2 \mathrm{~Hz}, 1 \mathrm{H}) .{ }^{13} \mathrm{C}$ NMR $(100$ $\left.\mathrm{MHz}, \mathrm{CDCl}_{3}, 300 \mathrm{~K}\right): \delta=166.7,139.3,134.9,133.46,133.41,131.2,119.2,52.2,21.3$.

Methyl-5-methoxy-o-toluate (5b). A solution of $4 \mathbf{c}(7.0 \mathrm{~g}, 42.1 \mathrm{mmol})$ in $\mathrm{MeOH}(300 \mathrm{~mL})$ containing $\mathrm{H}_{2} \mathrm{SO}_{4}(1.5 \mathrm{ml}, 26.5 \mathrm{mmol})$ was heated under reflux for $16 \mathrm{~h}$. The $\mathrm{MeOH}$ was removed under reduced pressure and the residue taken up in AcOEt $(250 \mathrm{~mL})$. The solution was washed with $\mathrm{H}_{2} \mathrm{O}(10 \mathrm{~mL})$. The aqueous layer was extracted with AcOEt $(50 \mathrm{~mL})$. The combined organic extracts were washed with saturated $\mathrm{NaHCO}_{3}(20 \mathrm{~mL})$ and $\mathrm{H}_{2} \mathrm{O}(2 \times 20 \mathrm{~mL})$ and dried $\left(\mathrm{MgSO}_{4}\right)$. The solvent was removed to afford the raw product $(7.4 \mathrm{~g})$. After purification by column chromatography $\left(\mathrm{SiO}_{2}\right.$, hexane/AcOEt, 1:1) the product was obtained as a yellow, oily liquid (7.1 g, 94\%). $\mathrm{R}_{\mathrm{f}}$ : (Hexane/AcOEt 1:1): 0.75. ${ }^{1} \mathrm{H} \mathrm{NMR}\left(400 \mathrm{MHz}, \mathrm{CDCl}_{3}, 300\right.$ $\mathrm{K}): \delta=7.44(\mathrm{~d}, J=4.0 \mathrm{~Hz}, 1 \mathrm{H}), 7.15(\mathrm{~d}, J=8.0 \mathrm{~Hz}, 1 \mathrm{H}), 6.96(\mathrm{dd}, J=8.0 \mathrm{~Hz}, 4.0 \mathrm{~Hz}, 1 \mathrm{H})$, $3.90(\mathrm{~s}, 3 \mathrm{H}), 3.82(\mathrm{~s}, 3 \mathrm{H}), 2.52(\mathrm{~s}, 3 \mathrm{H}) .{ }^{13} \mathrm{C} \mathrm{NMR}\left(100 \mathrm{MHz}, \mathrm{CDCl}_{3}, 300 \mathrm{~K}\right): \delta=167.9,157.3$, $132.6,132.1,130.1,118.4,115.0,55.4,51.8,20.8$.

Methyl-5-bromo-2-(dibromomethyl)-benzoate (6a). To a solution of 5a (10.0 g, $43.7 \mathrm{mmol})$ in $\mathrm{CCl}_{4}(20 \mathrm{~mL}) \mathrm{NBS}(23.3 \mathrm{~g}, 131.0 \mathrm{mmol})$, dibenzoylperoxide $(1.37 \mathrm{~g}, 5.6 \mathrm{mmol})$ and $\mathrm{CCl}_{4}(40$ $\mathrm{mL}$ ) were added. This mixture was refluxed for $15 \mathrm{~h}$ and then filtered to remove the solid. The filtrate was washed with saturated $\mathrm{Na}_{2} \mathrm{~S}_{2} \mathrm{O}_{3}, \mathrm{H}_{2} \mathrm{O}$ and dried $\left(\mathrm{MgSO}_{4}\right)$. The solvent was removed under reduced pressure and the solid residue dried in high vacuum $(1.5 \mathrm{~h})$ to afford a slightly yellow solid (17.1 g, quantitatively). mp: $97{ }^{\circ} \mathrm{C} .{ }^{1} \mathrm{H} \mathrm{NMR}\left(400 \mathrm{MHz}, \mathrm{CDCl}_{3}\right): \delta=8.04(\mathrm{~d}, J=$ $8.4 \mathrm{~Hz}, 1 \mathrm{H}), 8.04$ (dd, $J=2.3 \mathrm{~Hz}, 0.3 \mathrm{~Hz}, 1 \mathrm{H}), 7.97$ (d, $J=0.3 \mathrm{~Hz}, 1 \mathrm{H}), 7.75$ (ddd, $J=4.0 \mathrm{~Hz}$, 
$2.0 \mathrm{~Hz}, 0.48 \mathrm{~Hz}, 1 \mathrm{H}), 3.96(\mathrm{~s}, 1 \mathrm{H}) .{ }^{13} \mathrm{C} \mathrm{NMR}\left(100 \mathrm{MHz}, \mathrm{CDCl}_{3}\right): \delta=165.4,142.4,136.5$, 133.5, 133.0, 126.2, 123.5, 53.1, 37.1; IR (KBr): $v=3096(\mathrm{w}), 3071(\mathrm{~m}), 3018(\mathrm{~m}), 2954(\mathrm{~m})$, 1720 (s), 1587 (m), 1560 (s), 1479 (s), 1436 (s), 1385 (m), 1289 (s), 1259 (s), 1214 (m), 1191 (s), 1136 (s), 1099 (s), 1077 (s), 963 (s), 902 (m), 855 (m), 827 (s), 803 (s), $784(\mathrm{~m}), 724$ (s), 693 (s), 662 (s), 626 (s), 527 (m), 494 (m) ; MS (APCI) m/z (\%): 308.9 (45), 306.9 (100), 305.0 (45) [M$\mathrm{Br}]^{+}$.

Methyl-5-methoxy-2-(dibromomethyl)-benzoate (6b). This compound was synthesized using a similar procedure as for the synthesis of compound $\mathbf{6 a}$ : The solution of $\mathbf{5 b}(6.0 \mathrm{~g}, 33.2 \mathrm{mmol})$ dissolved in $\mathrm{CCl}_{4}(100 \mathrm{~mL})$ containing NBS $(17.8 \mathrm{~g}, 100 \mathrm{mmol})$ and a catalytic amount of dibenzoylperoxide was heated to reflux for $14 \mathrm{~h}$. After work-up as described for $\mathbf{6 a}$ the product was obtained as a slightly yellowish solid (11.9 g, quantitatively). $\mathrm{R}_{\mathrm{f}}$ (PE/AcOEt 2:1): 0.62. ${ }^{1} \mathrm{H}$ NMR $\left(400 \mathrm{MHz}, \mathrm{CDCl}_{3}, 300 \mathrm{~K}\right): \delta=8.09(\mathrm{~d}, J=8.8 \mathrm{~Hz}, 1 \mathrm{H}), 7.97(\mathrm{~s}, 1 \mathrm{H}), 7.34(\mathrm{~d}, J=2.8 \mathrm{~Hz}$, $1 \mathrm{H}), 7.15(\mathrm{dd}, J=8.8 \mathrm{~Hz}, 2.8 \mathrm{~Hz}, 1 \mathrm{H}), 3.95(\mathrm{~s}, 3 \mathrm{H}), 3.86(\mathrm{~s}, 3 \mathrm{H}) .{ }^{13} \mathrm{C} \mathrm{NMR}(100 \mathrm{MHz}$, $\left.\mathrm{CDCl}_{3}, 300 \mathrm{~K}\right): \delta=166.5,159.9,135.6,133.4,130.1,126.1,119.6,114.3,55.8,52.8,38.2$.

Methyl-bromo-2-formylbenzoat (1). In the absence of light compound 6a (16.9 g, $43.6 \mathrm{mmol})$ was suspended in $i$-PrOH $(300 \mathrm{~mL})$. To this mixture a solution of $\mathrm{AgNO}_{3}(14.8 \mathrm{~g}, 87.1 \mathrm{mmol})$ in $\mathrm{H}_{2} \mathrm{O}(30 \mathrm{~mL})$ was added over a period of $1 \mathrm{~h}$. After stirring for $1 \mathrm{~h}$ at RT a further portion of $\mathrm{AgNO}_{3}(0.25 \mathrm{~g}, 1.47 \mathrm{mmol})$ was added. After $4 \mathrm{~h}$ the transformation was complete as indicated by TLC. A saturated $\mathrm{NaCl}$ solution $(5 \mathrm{~mL})$ was added and the mixture was filtered over Celite. The $i$-PrOH was evaporated under reduced pressure. After dissolving the residue in $\mathrm{CH}_{2} \mathrm{Cl}_{2}(250$ $\mathrm{mL})$ this solution was washed with saturated $\mathrm{NaHCO}_{3}$ and $\mathrm{H}_{2} \mathrm{O}(20 \mathrm{~mL})$ and dried over $\mathrm{MgSO}_{4}$. The solvent was removed in a rotary evaporator to afford a yellowish solid (9.98 g, 94\%) which could be used for the next reactions. $\mathrm{R}_{\mathrm{f}}$ : (Hexane/AcOEt 4:1): 0.40. ${ }^{1} \mathrm{H} \mathrm{NMR}\left(400 \mathrm{MHz}, \mathrm{CDCl}_{3}\right.$, $300 \mathrm{~K}): \delta=10.58(\mathrm{~d}, J=0.6 \mathrm{~Hz}, 1 \mathrm{H}), 8.12(\mathrm{dd}, J=0.5 \mathrm{~Hz}, 2.0 \mathrm{~Hz}, 1 \mathrm{H}), 7.82(\mathrm{dd}, J=8.4 \mathrm{~Hz}$, $0.4 \mathrm{~Hz}, 1 \mathrm{H}), 7.79$ (ddd, $J=8.2 \mathrm{~Hz}, 1.8 \mathrm{~Hz}, 0.7 \mathrm{~Hz}, 1 \mathrm{H}), 3.99$ (s, $3 \mathrm{H}) .{ }^{13} \mathrm{C} \mathrm{NMR}(100 \mathrm{MHz}$, $\left.\mathrm{CDCl}_{3}, 300 \mathrm{~K}\right): \delta=191.0,165.5,135.7,133.6,133.4,130.1,128.1,53.2$; MS (APCI-positive) $\mathrm{m} / z(\%):=243.0(47), 241.1$ (47), 229.1 (57), 227.1 (56), 213.1 (100), 211.1 (96).

Methyl-2-formyl-3-o-octylbenzoate (8a). To a DMF solution (50 mL) of compound 1, $\mathrm{Pd}(\mathrm{OAc})_{2}(46 \mathrm{mg}, 0.206 \mathrm{mmol})$ and $\mathrm{P}(o-\mathrm{Tol})_{3}(125 \mathrm{mg}, 0.412 \mathrm{mmol})$ triethylamine $(3.5 \mathrm{~mL}$, $25.1 \mathrm{mmol})$ and 1-octene $(2.6 \mathrm{~mL}, 16.4 \mathrm{mmol})$ were added. This solution was heated to $100{ }^{\circ} \mathrm{C}$ for $16 \mathrm{~h}$. To the black mixture AcOEt $(200 \mathrm{~mL})$ was added and the solution was washed with saturated $\mathrm{NaCl}(50 \mathrm{~mL}), \mathrm{H}_{2} \mathrm{O}(2 \times 20 \mathrm{~mL})$ and dried $\left(\mathrm{MgSO}_{4}\right)$. The solvents were removed under reduced pressure. The raw product $(2.36 \mathrm{~g})$ was dissolved in $\mathrm{MeOH}(40 \mathrm{~mL})$ and trimethyl orthoformate $(20 \mathrm{~mL})$. After the addition of $\mathrm{NH}_{4} \mathrm{Cl}(40 \mathrm{mg}, 0.75 \mathrm{mmol})$ the mixture was heated to reflux for $16 \mathrm{~h}$. The solvents were removed in a rotary evaporator and to the residue EtOH (40 $\mathrm{mL}$ ) and $\mathrm{Pd} / \mathrm{C}(690 \mathrm{mg}, 0.647 \mathrm{mmol})$ were added. The hydrogenation under normal pressure was finished after $3 \mathrm{~h}$. The raw product was filtered over Celite. The solvent was then removed and the residue taken up in a mixture of THF $(30 \mathrm{~mL})$ and $2 \mathrm{~N} \mathrm{H}_{2} \mathrm{SO}_{4}(5 \mathrm{~mL})$. After stirring over night AcOEt $(150 \mathrm{~mL})$ and $\mathrm{H}_{2} \mathrm{O}(20 \mathrm{~mL})$ were added to the mixture. The organic phase was separated, then washed with saturated $\mathrm{NaHCO}_{3}(15 \mathrm{~mL})$ and $\mathrm{H}_{2} \mathrm{O}(10 \mathrm{~mL})$ and dried $\left(\mathrm{MgSO}_{4}\right)$. 
After the removal of the solvents the raw product was purified by column chromatography $\left(\mathrm{SiO}_{2}\right.$, hexane/AcOEt 4:1) to afford a yellow liquid (1.06 g, 47\%). $\mathrm{R}_{\mathrm{f}}$ (hexane/AcOEt 4:1): 0.68. ${ }^{1} \mathrm{H}$ NMR (400 MHz, $\left.\mathrm{CDCl}_{3}, 300 \mathrm{~K}\right): \delta=10.55(\mathrm{~d}, J=0.7 \mathrm{~Hz}, 1 \mathrm{H}), 7.87(\mathrm{~d}, J=7.9 \mathrm{~Hz}, 1 \mathrm{H}), 7.75$ $(\mathrm{d}, J=1.4 \mathrm{~Hz}, 1 \mathrm{H}), 7.44(\mathrm{ddd}, J=7.9 \mathrm{~Hz}, 1.7 \mathrm{~Hz}, 0.60 \mathrm{~Hz}, 1 \mathrm{H}), 3.97(\mathrm{~s}, 3 \mathrm{H}), 2.69$ (t, $J=7.8$ $\mathrm{Hz}, 2 \mathrm{H}), 1.63(\mathrm{~m}, 2 \mathrm{H}), 1.31-1.18(\mathrm{~m}, 10 \mathrm{H}), 0.87(\mathrm{t}, J=6.9 \mathrm{~Hz}, 3 \mathrm{H}) .{ }^{13} \mathrm{C} \mathrm{NMR}(100 \mathrm{MHz}$, $\left.\mathrm{CDCl}_{3}, 300 \mathrm{~K}\right): \delta=191.9,167.2,149.2,134.6,132.4,132.3,130.4,128.8,52.8,36.0,31.9,31.0$, 29.4, 29.3, 22.7, 14.2; MS (APCI-POS, [M + $\left.\mathrm{H}^{+}\right]$): $m / z(\%)=277$ (58), 245 (100) 244 (42).

4-octyl-benzaldehyde (8b). This compound was synthesized using the same method as described for 8a: yield: $1.90 \mathrm{~g}(81 \%)$ as a yellow oil. Rf (Hexane/AcOEt 4:1): 0.58. ${ }^{1} \mathrm{H}$ NMR $\left(400 \mathrm{MHz}, \mathrm{CDCl}_{3}, 300 \mathrm{~K}\right): \delta=9.97(\mathrm{~s}, 1 \mathrm{H}), 7.79(\mathrm{~d}, J=8.2 \mathrm{~Hz}, 2 \mathrm{H}), 7.33(\mathrm{~d}, J=8.0 \mathrm{~Hz}, 2 \mathrm{H})$, $2.68(\mathrm{t}, J=7.7 \mathrm{~Hz}, 2 \mathrm{H}), 1.63(\mathrm{~m}, 2 \mathrm{H}), 1.35-1.24(\mathrm{~m}, 10 \mathrm{H}), 0.87(\mathrm{t}, J=6.9 \mathrm{~Hz}, 3 \mathrm{H}) .{ }^{13} \mathrm{C}$ NMR (100 MHz, $\left.\mathrm{CDCl}_{3}, 300 \mathrm{~K}\right): \delta=192.1,150.6,134.4,133.1,130.0,129.2,36.3,31.9,31.2$, 29.5, 29.39, 29.33, 22.7, 14.2; MS (APCI-POS, [M+ $\left.\mathrm{H}^{+}\right] \mathrm{m} / z(\%): 219$ (100).

Porphyrin (9a). To $\mathrm{CH}_{2} \mathrm{Cl}_{2}(400 \mathrm{~mL})$ were added methyl-2-formyl-3-o-octylbenzoate $8 \mathbf{a}(1.42$ g, $5.13 \mathrm{mmol})$, 4-octylbenzaldehyde $8 \mathrm{~b}$ (3.37 g, $15.45 \mathrm{mmol})$, pyrrole (1.44 mL, $20.5 \mathrm{mmol})$ and benzyltributylammonium bromide $(20 \mathrm{mg})$. This solution was stirred for $10 \mathrm{~min}$. at RT under exclusion of light before adding $\mathrm{BF}_{3} \cdot \mathrm{Et}_{2} \mathrm{O}(0.26 \mathrm{~mL}, 2.06 \mathrm{mmol})$. After $15 \mathrm{~min}$. DDQ (4.67 g, $20.6 \mathrm{mmol}$ ) was added. The mixture was stirred over night and then neutralized with triethylamine $(17.0 \mathrm{~mL}, 123 \mathrm{mmol})$. The mixture was filtered over $\mathrm{SiO}_{2}$ by collecting the red filtrate. The solvents were removed in a rotary evaporator and the raw product purified by column chromatography affording a red solid (692 mg, 12\%). $\mathrm{R}_{\mathrm{f}}\left(\mathrm{Hexane} / \mathrm{CH}_{2} \mathrm{Cl}_{2}\right.$ 1:1): 0.58. ${ }^{1} \mathrm{H}$ NMR (400 MH, $\left.\mathrm{CDCl}_{3}, 300 \mathrm{~K}\right): \delta=8.85(\mathrm{~s}, 4 \mathrm{H}), 8.83(\mathrm{~d}, J=4.7 \mathrm{~Hz}, 2 \mathrm{H}), 8.67(\mathrm{~d}, J=4.7 \mathrm{~Hz}$, $2 \mathrm{H}), 8.20(\mathrm{~d}, J=1.8 \mathrm{~Hz}, 1 \mathrm{H}), 8.11(\mathrm{~m}, 6 \mathrm{H}), 8.03(\mathrm{~d}, J=7.7 \mathrm{~Hz}, 1 \mathrm{H}), 7.63(\mathrm{dd}, J=7.7 \mathrm{~Hz}$, $1.82 \mathrm{~Hz}, 1 \mathrm{H}), 7.54(\mathrm{~m}, 6 \mathrm{H}), 2.97(\mathrm{~m}, 8 \mathrm{H}), 2.70(\mathrm{~s}, 3 \mathrm{H}), 1.91(\mathrm{~m}, 8 \mathrm{H}), 1.53-1.20(\mathrm{~m}, 40 \mathrm{H})$, $0.94(\mathrm{~m}, 12 \mathrm{H}),-2.68$ (s br, $2 \mathrm{H})$. UV-vis $\left(\mathrm{CH}_{2} \mathrm{Cl}_{2}\right): \lambda(\%)=374$ (6), 421 (100), 518 (5), 554 (3), 593 (2), 649 (2). MS (APCI-NEG, [M - H]-, MeOH): $m / z(\%)=1121$ (100). HR-MALDI-MS (POS, Matrix: DCTB, $\left[\mathrm{M}+\mathrm{H}^{+}\right]$): calc. $\mathrm{C}_{78} \mathrm{H}_{97} \mathrm{~N}_{4} \mathrm{O}_{2}$ 1121.76, found: 1121.75 .

Tetrakis-p-octyl-TPP (9b). This compound was synthesized using the same method as described for the synthesis of 9a. After purification by column chromatography $\left(\mathrm{SiO}_{2}\right.$, hexane $/ \mathrm{CH}_{2} \mathrm{Cl}_{2}$ 1:1) a red solid $(1.0 \mathrm{~g}, 45 \%)$ was obtained. $\mathrm{R}_{\mathrm{f}}\left(\right.$ Hexane $/ \mathrm{CH}_{2} \mathrm{Cl}_{2}$ 1:1): 0.84. ${ }^{1} \mathrm{H}$ NMR $\left(200 \mathrm{MHz}, \mathrm{CDCl}_{3}, 300 \mathrm{~K}\right): \delta=8.87(\mathrm{~s}, 8 \mathrm{H}), 8.12(\mathrm{~d}, J=7.9 \mathrm{~Hz}, 8 \mathrm{H}), 7.56(\mathrm{~d}, J=8.1 \mathrm{~Hz}$, $8 \mathrm{H}), 2.96(\mathrm{t}, J=7.6 \mathrm{~Hz}, 8 \mathrm{H}), 1.91(\mathrm{~m}, 8 \mathrm{H}), 1.54-1.27(\mathrm{~m}, 10 \mathrm{H}), 0.95(\mathrm{t}, J=6.5 \mathrm{~Hz}, 12 \mathrm{H})$, 2.74 (s br, $2 \mathrm{H})$.

Ni-Oxonaphthoporphyrin (10a). The porphyrin 9a (112 $\mathrm{mg}, 100 \mu \mathrm{mol})$ was dissolved in toluene $(50 \mathrm{~mL})$ and heated to reflux for $16 \mathrm{~h}$ in the presence of $\mathrm{Ni}(\mathrm{acac})_{2}(51 \mathrm{mg}, 200 \mu \mathrm{mol})$. The solution was diluted with toluene $(50 \mathrm{~mL})$, washed with $\mathrm{H}_{2} \mathrm{O}(2 \times 50 \mathrm{~mL})$ and dried $\left(\mathrm{MgSO}_{4}\right)$. The solvent was removed under reduced pressure. A red solid (118 mg) was obtained, which was dissolved in dioxane $(20 \mathrm{~mL})$ and mixed with a solution of $\mathrm{KOH}(2.0 \mathrm{~g}, 35.6 \mathrm{mmol})$ in $\mathrm{H}_{2} \mathrm{O}(10 \mathrm{~mL})$. This mixture was heated to reflux $(20 \mathrm{~h})$ and after cooling poured on toluene $(50 \mathrm{~mL})$. Acidification with concentrated $\mathrm{HCl}$ gave a clear, red solution that was washed with 
saturated $\mathrm{NaCl}, \mathrm{H}_{2} \mathrm{O}(2 \times 20 \mathrm{~mL})$ and dried $\left(\mathrm{MgSO}_{4}\right)$. After removing the solvent in a rotary evaporator, the compound was dried under high vacuum. To this solid benzene $(50 \mathrm{~mL})$ and oxalic chloride $(1.0 \mathrm{~mL}, 11.8 \mathrm{mmol})$ were added. The mixture was heated to reflux $(18 \mathrm{~h})$, then $5.0 \mathrm{~mL}$ were distilled off. To this solution $\mathrm{SnCl}_{4}(235 \mu \mathrm{L}, 2.0 \mathrm{mmol})$ was added at RT. After stirring for $1 \mathrm{~h}$, the mixture was poured into toluene $(100 \mathrm{~mL})$ and washed subsequently with aq. $\mathrm{NaOH}(1 \mathrm{M}, 50 \mathrm{~mL})$ and $\mathrm{H}_{2} \mathrm{O}(3 \mathrm{x} 100 \mathrm{~mL})$. The solvents were removed after drying over $\mathrm{MgSO}_{4}$. The raw product was purified by column chromatography $\left(\mathrm{SiO}_{2}, \mathrm{PE} / \mathrm{CH}_{2} \mathrm{Cl}_{2} 1: 1\right)$ and SEC (toluene). Drying on the HV afforded a green, pasty solid (105 $\mathrm{mg}, 92 \%)$. $\mathrm{R}_{\mathrm{f}}$ (petroleum ether $/ \mathrm{CH}_{2} \mathrm{Cl}_{2}$ 1:1): 0.72. ${ }^{1} \mathrm{H} \mathrm{NMR}\left(400 \mathrm{MHz}, \mathrm{CDCl}_{3}, 300 \mathrm{~K}\right) \delta=9.19(\mathrm{~d}, J=5.1 \mathrm{~Hz}, 1 \mathrm{H}), 9.17$ $(\mathrm{d}, J=4.0 \mathrm{~Hz}, 1 \mathrm{H}), 9.15(\mathrm{~s}, 1 \mathrm{H}), 8.66(\mathrm{~d}, J=5.1 \mathrm{~Hz}, 1 \mathrm{H}), 8.50(\mathrm{~d}, J=5.0 \mathrm{~Hz}, 1 \mathrm{H}), 8.47(\mathrm{~d}, J$ $=5.0 \mathrm{~Hz}, 1 \mathrm{H}), 8.39(\mathrm{~d}, J=3.1 \mathrm{~Hz}, 1 \mathrm{H}), 8.37(\mathrm{~d}, J=5.7 \mathrm{~Hz}, 1 \mathrm{H}), 8.26(\mathrm{~d}, J=8.0 \mathrm{~Hz}, 1 \mathrm{H}), 7.84$ $(\mathrm{d}, J=8.0 \mathrm{~Hz}, 1 \mathrm{H}), 7.80(\mathrm{~m}, 9 \mathrm{H}), 7.49(\mathrm{dd}, J=8.4 \mathrm{~Hz}, 1.8 \mathrm{~Hz}, 1 \mathrm{H}), 7.45(\mathrm{~m}, 9 \mathrm{H}), 2.85$ (m, 6 $\mathrm{H}), 2.76(\mathrm{t}, J=7.7 \mathrm{~Hz}, 2 \mathrm{H}), 1.81(\mathrm{~m}, 8 \mathrm{H}), 1.51-1.27(\mathrm{~m}, 40 \mathrm{H}), 0.95-0.85(\mathrm{~m}, 12 \mathrm{H})$. UV-vis $\left(\mathrm{CH}_{2} \mathrm{Cl}_{2}\right): \lambda(\%)=324$ (23), 385 (35), 465 (100), 648 (12). HR-MALDI-MS (POS mode, matrix: DCTB, $[\mathrm{M}]^{+}$): calc. $\mathrm{C}_{77} \mathrm{H}_{90} \mathrm{~N}_{4} \mathrm{NiO} 1144.646$, found: 1144.66 .

Cu-Oxonaphthoporphyrin (10b). A solution of the porphyrin $9 b$ (500 $\mathrm{mg}, 0.47 \mathrm{mmol}$ ) in $\mathrm{CH}_{2} \mathrm{Cl}_{2} / \mathrm{MeOH}(100 \mathrm{~mL} / 50 \mathrm{~mL})$ was heated to reflux in the presence of $\mathrm{Cu}(\mathrm{OAc})_{2}(855 \mathrm{mg}, 4.7$ mmol) for $16 \mathrm{~h}$. The mixture was taken up in $\mathrm{CH}_{2} \mathrm{Cl}_{2}(100 \mathrm{~mL})$ and washed with $\mathrm{H}_{2} \mathrm{O}(20 \mathrm{~mL})$. The aqueous layer was re-extracted with $\mathrm{CH}_{2} \mathrm{Cl}_{2}(20 \mathrm{~mL})$. The whole procedure was repeated two times before drying $\left(\mathrm{MgSO}_{4}\right)$. The copper complex $(100 \mathrm{mg}, 89 \mu \mathrm{mol})$ obtained after removal of the solvents was heated to reflux in a solution containing 1,2-dichloroethane $(20 \mathrm{~mL})$, DMF $(0.5 \mathrm{~mL})$ and $\mathrm{POCl}_{3}(0.5 \mathrm{~mL})$. After $18 \mathrm{~h}$ the entire mixture was poured on a solution of sodium acetate $(10 \mathrm{~g})$ in $\mathrm{H}_{2} \mathrm{O}(40 \mathrm{~mL})$ and stirred for $1 \mathrm{~h}$. After addition of $\mathrm{CH}_{2} \mathrm{Cl}_{2}(100 \mathrm{~mL})$ and the separation of the two phases, the aqueous layer was extracted with $\mathrm{CH}_{2} \mathrm{Cl}_{2}(20 \mathrm{~mL})$. The combined organic phases were washed with $\mathrm{H}_{2} \mathrm{O}(3 \times 20 \mathrm{~mL})$ and dried $\left(\mathrm{MgSO}_{4}\right)$. Evaporation of the solvents afforded a brown solid $(200 \mathrm{mg}$ ) which was used as such for the next step. The raw product was dissolved in a mixture of 1,2-dichloroethane/benzene $(20 \mathrm{~mL} / 2 \mathrm{~mL})$, $\mathrm{TsOH} \cdot \mathrm{H}_{2} \mathrm{O}(15 \mathrm{mg}, 79 \mu \mathrm{mol})$ and chloranil $(45 \mathrm{mg}, 183 \mu \mathrm{mol})$ and heated to reflux during $16 \mathrm{~h}$. After the addition of $\mathrm{CH}_{2} \mathrm{Cl}_{2}(200 \mathrm{~mL})$ the solution was poured in a beaker containing saturated $\mathrm{NaHCO}_{3}(50 \mathrm{~mL})$ and stirred for $10 \mathrm{~min}$. at RT. The aqueous layer was extracted with $\mathrm{CH}_{2} \mathrm{Cl}_{2}$ $(50 \mathrm{~mL})$. The organic extracts were washed with $\mathrm{H}_{2} \mathrm{O}(2 \times 50 \mathrm{~mL})$ and dried $\left(\mathrm{MgSO}_{4}\right)$. The solvents were distilled off under reduced pressure and the raw product purified by column chromatography $\left(\mathrm{SiO}_{2}\right.$, hexane $/ \mathrm{CH}_{2} \mathrm{Cl}_{2} 2: 3$ ) affording a brown-green solid (34 mg, 33\%). $\mathrm{R}_{\mathrm{f}}$ (Hexane/ $\mathrm{CH}_{2} \mathrm{Cl}_{2}$ 1:2): 0.72. UV-Vis $\left(\mathrm{CH}_{2} \mathrm{Cl}_{2}\right): \lambda(\%)=327$ (19), 392 (29), 420 (24), 463 (100), 656 (12); HR-MALDI-MS (POS-mode, matrix: DCTB, $[\mathrm{M}+\mathrm{H}]^{+}$): calc. $\mathrm{C}_{77} \mathrm{H}_{91} \mathrm{CuN}_{4} \mathrm{O}$ 1150.648, found: 1150.643 .

Oxonaphthoporphyrin (12a). The Ni-oxonaphthoporphyrin 11 (200 mg, $244 \mu \mathrm{mol})$ was suspended in a mixture of TFA $/ \mathrm{H}_{2} \mathrm{SO}_{4}(40 \mathrm{~mL} / 8 \mathrm{~mL})$ and stirred at RT for $30 \mathrm{~min}$. Then the solution was poured on ice water $(200 \mathrm{~mL})$ and neutralized carefully by slow addition of saturated $\mathrm{NaHCO}_{3}$. The product was extracted with $\mathrm{CH}_{2} \mathrm{Cl}_{2}(3 \times 100 \mathrm{~mL})$. The combined organic 
extracts were washed with $\mathrm{H}_{2} \mathrm{O}(100 \mathrm{~mL})$ and dried $\left(\mathrm{MgSO}_{4}\right)$. After filtration the solvent was removed under reduced pressure affording a green, powdery solid (121 mg, 65\%). The free base oxonaphthoporphyrin $(120 \mathrm{mg}, 157 \mu \mathrm{mol})$ was treated with a $\mathrm{BBr}_{3}$-solution $(4 \mathrm{~mL}, 1 \mathrm{M}$ in $\left.\mathrm{CH}_{2} \mathrm{Cl}_{2}\right)$ and the mixture diluted with $\mathrm{CH}_{2} \mathrm{Cl}_{2}(30 \mathrm{~mL})$. The reaction was stirred at RT for $20 \mathrm{~h}$, then $\mathrm{CH}_{2} \mathrm{Cl}_{2}(25 \mathrm{~mL})$ was added and the mixture was neutralized with saturated $\mathrm{NaHCO}_{3}(10$ $\mathrm{mL})$. The organic extract was washed with $\mathrm{H}_{2} \mathrm{O}(2 \times 10 \mathrm{~mL})$ and dried $\left(\mathrm{MgSO}_{4}\right)$. Evaporation of the solvent gave a solid, that was purified by column chromatography $\left(\mathrm{SiO}_{2}, \mathrm{CH}_{2} \mathrm{Cl}_{2} / \mathrm{MeOH} 9: 1\right.$ to $8: 2$ ) affording a green solid (87 $\mathrm{mg}, 78 \%$ ). The tetrahydroxyoxonaphthoporphyrin (15 $\mathrm{mg}$, $21 \mu \mathrm{mmol})$ was dissolved in a mixture of toluene/DMF/triethylamine $(10 \mathrm{~mL}: 2 \mathrm{~mL}: 0.4 \mathrm{~mL})$ and treated with decanoyl chloride $(290 \mu \mathrm{L}, 1.41 \mathrm{mmol})$. After heating the mixture for $16 \mathrm{~h}$ to reflux the reaction mixture was diluted with toluene $(100 \mathrm{~mL})$ and washed with saturated $\mathrm{NaHCO}_{3}(25$ $\mathrm{mL})$ and $\mathrm{H}_{2} \mathrm{O}(2 \times 10 \mathrm{~mL})$. The organic phase was dried $\left(\mathrm{MgSO}_{4}\right)$ and the solvents were removed in a rotary evaporator. The raw product was dried in high vacuum for $2 \mathrm{~h}$ and then purified by column chromatography $\left(\mathrm{SiO}_{2}, \mathrm{CH}_{2} \mathrm{Cl}_{2} / \mathrm{MeOH}\right.$ 200:1) and size exclusion chromatography (toluene) affording a green, pasty solid (13 mg, 46\%). $\mathrm{R}_{\mathrm{f}}\left(\mathrm{CH}_{2} \mathrm{Cl}_{2} / \mathrm{MeOH} 200: 1\right): 0.92 .{ }^{1} \mathrm{H} \mathrm{NMR}$ $\left(400 \mathrm{MHz}, \mathrm{CDCl}_{3}, 300 \mathrm{~K}\right): \delta=9.30(\mathrm{~d}, J=4.3 \mathrm{~Hz}, 1 \mathrm{H}), 9.23(\mathrm{~s}, 1 \mathrm{H}), 8.65(\mathrm{~d}, J=5.4 \mathrm{~Hz}, 1 \mathrm{H})$, $8.63(\mathrm{~d}, J=5.4 \mathrm{~Hz}, 1 \mathrm{H}), 8.57$ (t, $J=3.2 \mathrm{~Hz}, 2 \mathrm{H}), 8.52(\mathrm{~d}, J=6.5 \mathrm{~Hz}, 1 \mathrm{H}), 8.36(\mathrm{~d}, J=8.6 \mathrm{~Hz}$, $1 \mathrm{H}), 8.19(\mathrm{~d}, J=3.2 \mathrm{~Hz}, 1 \mathrm{H}), 8.12(\mathrm{~s}, 1 \mathrm{H}), 8.06(\mathrm{~m}, 5 \mathrm{H}), 7.54(\mathrm{dd}, J=8.6 \mathrm{~Hz}, 3.2 \mathrm{~Hz}, 1 \mathrm{H})$, $7.49(\mathrm{~m}, 6 \mathrm{H}), 2.72(\mathrm{~m}, 8 \mathrm{H}), 1.89(\mathrm{~m}, 8 \mathrm{H}), 1.58-1.26(\mathrm{~m}, 48 \mathrm{H}), 0.91(\mathrm{~m}, 12 \mathrm{H}),-0.60$ (s br, 2 H). ${ }^{13} \mathrm{C} \mathrm{NMR}\left(100 \mathrm{MHz}, \mathrm{CDCl}_{3}, 300 \mathrm{~K}\right): \delta=183.6,172.6,172.5,172.4,151.3,151.1,150.8$, $140.0,138.5,138.4,137.9,137.5,135.5,135.4,135.1,126.9,125.3,122.4,122.1,120.5,120.4$, $120.1,110.8,34.8,34.7,32.1,29.6,29.5,29.4,25.3,25.2,22.9,14.3 ; \mathrm{UV}$-vis $\left(\mathrm{CH}_{2} \mathrm{Cl}_{2}\right): \lambda(\%)=$ 331 (25), 383 (38), 417 (35), 467 (100), 580 (5), 645 (8), 750 (9); HRMS (ESI-POS) [M + H+], calc. $\mathrm{C}_{85} \mathrm{H}_{101} \mathrm{~N}_{4} \mathrm{O}_{9} 1321.756$, found: 1321.77 .

Oxonaphthoporphyrin (12b). This compound was synthesized using the same procedure as described for 12a giving a green, pasty solid (14 mg, 46\%). $\mathrm{R}_{\mathrm{f}}\left(\mathrm{CH}_{2} \mathrm{Cl}_{2} / \mathrm{MeOH} 200: 1\right): 0.75 .{ }^{1} \mathrm{H}-$ NMR $\left(400 \mathrm{MHz}, \mathrm{CDCl}_{3}, 300 \mathrm{~K}\right): \delta=9.29(\mathrm{~d}, J=5.0 \mathrm{~Hz}, 1 \mathrm{H}), 9.22(\mathrm{~s}, 1 \mathrm{H}), 8.64(\mathrm{~d}, J=5.4 \mathrm{~Hz}$, $1 \mathrm{H}), 8.63(\mathrm{~d}, J=5.1 \mathrm{~Hz}, 1 \mathrm{H}), 8.57(\mathrm{t}, J=4.9 \mathrm{~Hz}, 2 \mathrm{H}), 8.52(\mathrm{~d}, J=4.8 \mathrm{~Hz}, 1 \mathrm{H}), 8.34(\mathrm{~d}, J=$ $8.6 \mathrm{~Hz}, 1 \mathrm{H}), 8.18(\mathrm{~d}, J=2.6 \mathrm{~Hz}, 1 \mathrm{H}), 8.09(\mathrm{~m}, 6 \mathrm{H}), 7.52(\mathrm{dd}, J=8.6 \mathrm{~Hz}, 2.6 \mathrm{~Hz}, 1 \mathrm{H}), 7.48$ $(\mathrm{m}, 6 \mathrm{H}), 2.72(\mathrm{~m}, 8 \mathrm{H}), 1.89(\mathrm{~m}, 8 \mathrm{H}), 1.58-1.26(\mathrm{~m}, 64 \mathrm{H}), 0.90(\mathrm{~m}, 12 \mathrm{H}),-0.61(\mathrm{~s} \mathrm{br}, 2 \mathrm{H})$ ppm. UV-vis $\left(\mathrm{CH}_{2} \mathrm{Cl}_{2}\right): \lambda(\%)=331$ (25), 385 (38), 418 (35), 466 (100), 585 (6), 645 (8), 748 (9); HRMS (ESI-POS, THF/HCOOH, $\left[\mathrm{M}+\mathrm{H}^{+}\right]$, calc. $\mathrm{C}_{93} \mathrm{H}_{117} \mathrm{~N}_{4} \mathrm{O}_{9}$ 1433.882, found: 1433.880.

Oxonaphthoporphyrin (12c). The 3,5-Didodecanoylbenzoyl-chloride (435 $\mathrm{mg}, 0.852 \mathrm{mmol}$ ) was treated with the tetrahydroxyoxonaphthoporphyrin $(15 \mathrm{mg}, 21 \mu \mathrm{mol})$ and dissolved in $\mathrm{DMF} /$ toluene/ $\mathrm{NEt}_{3}(3 \mathrm{~mL}: 15 \mathrm{~mL}: 240 \mu \mathrm{L})$ and heated to reflux. After $16 \mathrm{~h}$ a low conversion was observed by TLC. Additional the acid chloride (435 $\mathrm{mg}, 0.852 \mathrm{mmol}$ ) in toluene $(10 \mathrm{~mL})$ was added. This procedure was repeated after $6 \mathrm{~h}$ and heating continued for further $16 \mathrm{~h}$. The reaction mixture was poured in toluene $(100 \mathrm{~mL})$, washed with saturated $\mathrm{NaHCO}_{3}(25 \mathrm{~mL})$ and $\mathrm{H}_{2} \mathrm{O}(2 \times 10 \mathrm{~mL})$ and dried $\left(\mathrm{MgSO}_{4}\right)$. The obtained raw product was purified by column chromatography $\left(\mathrm{SiO}_{2}, \mathrm{CH}_{2} \mathrm{Cl}_{2} / \mathrm{MeOH} 200: 1\right)$ and size exclusion chromatography (toluene) 
affording a green, pasty solid (15 mg, 27\%). $\mathrm{R}_{\mathrm{f}}\left(\mathrm{CH}_{2} \mathrm{Cl}_{2} / \mathrm{AcOEt} 19: 1\right): 0.82 .{ }^{1} \mathrm{H} \mathrm{NMR}(400 \mathrm{MHz}$, $\left.\mathrm{CDCl}_{3}, 300 \mathrm{~K}\right): \delta=9.36(\mathrm{~d}, J=4.7 \mathrm{~Hz}, 1 \mathrm{H}), 9.27(\mathrm{~s}, 1 \mathrm{H}), 8.71(\mathrm{t}, J=5.3 \mathrm{~Hz}, 2 \mathrm{H}), 8.65(\mathrm{t}, J=$ $5.1 \mathrm{~Hz}, 2 \mathrm{H}), 8.59(\mathrm{~d}, J=4.8 \mathrm{~Hz}, 1 \mathrm{H}), 8.41(\mathrm{~d}, J=8.6 \mathrm{~Hz}, 1 \mathrm{H}), 8.32(\mathrm{~d}, J=2.4 \mathrm{~Hz}, 1 \mathrm{H}), 8.19$ $(\mathrm{d}, J=8.7 \mathrm{~Hz}, 2 \mathrm{H}), 8.15(\mathrm{~d}, J=7.56 \mathrm{~Hz}, 2 \mathrm{H}), 7.68(\mathrm{dd}, J=8.4 \mathrm{~Hz}, 2.5 \mathrm{~Hz}, 1 \mathrm{H}), 7.63(\mathrm{t}, J=8.5$ $\mathrm{Hz}, 5 \mathrm{H}), 7.50(\mathrm{~m}, 6 \mathrm{H}), 7.43(\mathrm{~d}, J=2.2 \mathrm{~Hz}, 3 \mathrm{H}), 7.36(\mathrm{~s}, 3 \mathrm{H}), 6.79(\mathrm{~m}, 4 \mathrm{H}), 4.09(\mathrm{~m}, 16 \mathrm{H})$, $1.85(\mathrm{~m}, 16 \mathrm{H}), 1.52(\mathrm{~m}, 16 \mathrm{H}), 1.39-1.15(\mathrm{~m}, 128 \mathrm{H}), 0.89(\mathrm{~m}, 48 \mathrm{H}),-0.55$ (s br, $2 \mathrm{H})$; UVvis $\left(\mathrm{CH}_{2} \mathrm{Cl}_{2}\right): \lambda(\%)=325$ (36), 339 (41), 419 (42), 467 (100), 581 (7), 647 (10), 743 (11). HRMALDI-MS (DCTB Matrix, $\left[\mathrm{M}+\mathrm{H}^{+}\right.$], calc. $\mathrm{C}_{169} \mathrm{H}_{237} \mathrm{~N}_{4} \mathrm{O}_{17} 2594.780$, found: 2595.71 .

\section{Acknowledgements}

We thank Prof. R. Deschenaux and Dr. S. Gothis for the measurements with polarized light microscopy and their help in the interpretation. This work was financially supported by the Swiss National Science Foundation (SNF) and the Canton of Neuchâtel (Switzerland).

\section{References}

1. (a) Nakamura, Y.; Aratani, N.; Osuka, A. Chem. Soc. Rev. 2007, 36, 831 (b) Satake, A.; Kobuke, Y. Org. Biomol. Chem. 2007, 5, 1679. (c) Balaban, T. S. Acc. Chem. Res. 2005, 38, 612.

2. (a) Mansuy, D. C. R. Acad. Sci. II C 2007, 10, 392. (b) Woggon, W.-D. Acc. Chem. Res. 2005, 38, 127.

3. (a) Collman J. P.; Fu, L. Acc. Chem. Res. 1999, 32, 455. (b) Collman, J.-P.; Boulatov, R.; Sunderland, C. J.; Fu, L. Chem. Rev. 2004, 104, 561.

4. (a) Pandey, R. K.; Zheng, G. Porphyrin Handbook Vol. 6 Eds., Kadish, K. M.; Smith, K. M.; Guilard, R. Academic Press: San Diego 2000, pp 57-230. (b) Sessler, J. L.; Tvermoes, N. A.; Davis, J.; Anzenbacher, Jr., P.; Jursikov, K.; Sato, W.; Seidel, D.; Lynch, V.; Black, C. B.; Try, A.; Andrioletti, B.; Hemmi, G.; Mody, T. D.; Magda, D. J.; Kral, V. Pure Appl. Chem. 1999, 71, 2009.

5. (a) Schouten, P. G.; Warman, J. M.; de Haas, M. P.; Fox, M. A.; Pan, H. L. Nature 1991, 353, 736. (b) Goodby, J. W.; Robinson, P. S.; Teo, B. K.; Cladis, P. E. Mol. Cryst. Liq. Cryst. 1980, 56, 303. (c) Ohta, K.; Yamaguchi, N.; Yamamoto, I. J. Mater. Chem. 1998, 8, 2637. (d) Wang, Q. M.; Bruce, D. W. Angew. Chem. Int. Ed. 1997, 36, 150. (e) Monobe, H.; Mima, S.; Sugino, T.; Shimizu,Y. J. Mater. Chem. 2001, 11, 1383. (f) Kang, S. W.; Li, Q.; Chapman, B. D.; Pindak, R.; Cross, J. O.; Li, L.; Nakata, M.; Kumar, S. Chem. Mater. 2007, 19, 5657. (g) Li, Q.; Li, L.; Jakli, A.; Harden, J. U. S. Pat. 2007, US 2007/0152189 A1. (h) Li, J.; Xin, H.; Li, M. Liquid Crystals 2006, 33, 913. (i) Yu, M.; Liu, G. F.; Cui, X. L. J. Porphyrins Phthalocyanins 2005, 9, 231. 
6. Shimizu, Y.; Miya, M.; Nagata, A.; Ohta, K.; Yamamoto, I.; Kusabayashi, S. Liq. Cryst. 1993, 14, 795.

7. Liu, W.; Shi, Y.; Shi, T.; Liu, G.; Liu, Y.; Wang, C.; Zhang, W. Liq. Cryst. 2003, 30, 1255.

8. Henrick, K.; Owston, P. G.; Peters, R.; Tasker, P. A. Inorg. Chim. Acta 1980, 45, L161L163.

9. McCarthy, J. R.; Hyland, M. A.; Brückner, C. Org. Biomol. Chem. 2004, 2, 1484.

10. Ventura, B.; Flamigni, L.; Marconi, G.; Lodato, F.; Officer, D. L. New J. Chem. 2008, 32, 166.

11. Richardson, C.; Reed, C. A. J. Org. Chem. 2007, 72, 4750.

12. Callot, H. J.; Schaeffer, E.; Cromer, R.; Metz, F. Tetrahedron 1990, 46, 5253.

13. Jasinski, S.; Ermilov, E. A.; Jux, N.; Röder, B. Eur. J. Org. Chem. 2007, 7, 1075.

14. Richeter, S.; Jeandon, E.; Gisselbrecht, J. P.; Ruppert, R.; Callot, H. J. J. Am. Chem. Soc. 2002, 124, 6168.

15. S. Richeter, S.; Jeandon, C.; Kyritsakas, N.; Ruppert, R.; Callot, H. J. J. Org. Chem. 2003, $68,9200$.

16. Silva, A. M. G.; Faustino, M. A. F.; Silva, T. M. P. C.; Neves, M. G. M. S.; Tomé, A. C.; Silva, A. M. S.; Cavaleiro, J. A. S. J. Chem. Soc., Perkin Trans 1 2002, 1774.

17. (a) Rokach, J.; Cragoe, E. J.; Rooney, C. S. U.S. Pat. 1981, 4282 365. (b) Moorthy, J. N.; Singhal, N.; Senapati, K. Tetrahedron Lett. 2006, 47, 1757.(c) Lartia, R.; Allain, C.; Bordeau, G.; Schmidt, F.; Fiorini-Debuisschert, C.; Charra, F.; Teulade-Fichou, M.-P. J. Org. Chem. 2008, 73, 1732.

18. (a) Newman, M. S.; Bayerlein, F. J. Org. Chem. 1963, 28, 2804. b) Hartmann, R. W.; Heindl, A.; Schoenenberger, H. J. Med. Chem. 1984, 27, 577.(c) Randad, R. S.; Lubkowska, L.; Bhat, T. N.; Munshi, S.; Gulnik, S. V.; Yu, B.; Erickson, J. W. Bioorg. Med. Chem. Lett. 1995, 5, 1707.

19. Otake, H.; Tsutsumi, H.; Murata, M. Jap. Pat. 1997, JP 09263549.

20. Herzog, B. Ph.D. thesis, Neuchatel, 2008.

21. Nakata, M. European Pat. 2003, EP 1364947 A1.

22. Buggy, T.; Ellis, G. P. J. Chem. Res.-S 1980, 159.

23. Hung, T. V.; Mooney, B. A.; Prager, R. H.; Ward, A. D. Aust. J. Chem. 1981, 34, 151.

24. Heck, R. F. Organic Reactions 1982, 27, 345.

25. F. Berthiol, H. Doucet, M. Santelli, Tetrahedron Lett. 2003, 44, 1221.

26. Azzena, U.; Idini, M. V.; Pilo, L. Synth. Commun. 2003, 33, 1309.

27. Li, F.; Yang, K.; Tyhonas, J. S.; MacCrum, K. A.; Lindsey, J. S. Tetrahedron 53, 12339.

28. Lindsey, J. S.; Hsu, H.-C.; Schreiman, I. C. Tetrahedron Lett. 27, 4969-4970.

29. Barloy, L.; Dolphin, D.; Dupre, D.; Wijesekera, T. P.J. Org. Chem. 1994, 59, 7976-7985.

30. Gottlieb, H. E.; Kotlyar, V.; Nudelman, A. J. Org. Chem. 1997, 62, 7512. 